\title{
Penelitian Bidang Ilmu Sosial pada Jurnal Studia Islamika Tahun 2014 -2018
}

\author{
Rochani Nani Rahayu' ${ }^{*}$; Tupan ${ }^{1}$ \\ ${ }^{1}$ Pusat Data dan Dokumentasi Ilmiah LIPI \\ *Korespondensi: nanipdii@yahoo.com
}

\begin{abstract}
A bibliometric study of research in the social sciences was conducted in the Studia Islamika Journal. The research uses a search method of the Studia Islamika journal using the Scopus database, (http: www.scopus.com) with a range of observation years is 2014 - 2018. Search results are grouped by year of publication, number of articles published, topics of interest to researchers, and author productivity. The results of the study indicate that Studia Islamika is one of the journals on Islamic studies published by the Syarif Hidayatullah State Islamic University Jakarta. Studia Islamika has been worldwide as evidenced by among others its contributors not only from Indonesia, but also from various institutions from other countries such as Australia, America, Japan, India, and Malaysia. Moreover the journal has been indexed by Scopus. The most written documents were in review format compared to articles and papers with the number of citations during 2014 -2018 is 862 times. The most author is from Syarif Hidayatullah State Islamic University and the most productive writer is Darmadi.
\end{abstract}

Keywords: bibliometrics; studia islamika; social sciences

\begin{abstract}
Abstrak
Sebuah kajian bibliometrik dilakukan terhadap penelitian bidang ilmu sosial pada Jurnal Studia Islamika dengan tujuan untuk mengetahui jumlah artikel, topik, pengarang terproduktif, jenis dokumen, negara asal penulis dan jumlah sitasi. Penelitian menggunakan metode penelusuran terhadap jurnal Studia Islamika, dengan memanfaatkan database Scopus, (http: www.scopus.com) dengan rentang tahun pengamatan adalah 2014 - 2018. Hasil penelusuran dikelompokkan berdasarkan tahun terbit, jumlah artikel yang diterbitkan, topik yang menjadi minat peneliti, dan produktivitas pengarang. Hasil penelitian menunjukkan bahwa Studia Islamika merupakan salah satu jurnal tentang studi Islam terbitan Universitas Islam Negeri Syarif Hidayatullah Jakarta. Studia Islamika telah dikenal di dunia yang dibuktikan antara lain para kontributornya tidak hanya dari Indonesia, namun juga berasal dari berbagai institusi dari negara lain seperti Australia, Amerika, Jepang, India, dan Malaysia. Jurnal ini pun telah diindeks oleh Scopus. Tinjauan merupakan dokumen paling banyak ditulis dibandingkan dengan artikel serta makalah dengan jumlah kutipan selama tahun 2014 -2018 adalah 862 kali. Penulis terbanyak berasal dari UIN Syarif Hidayatullah dan penulis paling produktif adalah Darmadi.
\end{abstract}

Kata Kunci: bibliometrik; studia islamika; ilmu sosial

\section{PENDAHULUAN}

Bibliometrika adalah sebuah studi penelitian kuantitatif dari berbagai aspek jurnal penelitian atau literatur tentang suatu topik (Sridevi, T.R., 2014). Analisis bibliometrik pada dasarnya adalah teknik analisis kutipan yang melibatkan proses pengumpulan, penghitungan, analisis \& interpretasi kutipan yang diberikan dalam berbagai jenis literatur dan dengan demikian membantu dalam mengidentifikasi sumber informasi yang signifikan. Ini adalah unit pendorong penelitian yang muncul di bidang perpustakaan dan ilmu informasi. Studi Bibliometrik semacam itu telah digunakan untuk menyelidiki topik-topik seperti pertumbuhan dan tren penelitian untuk mengevaluasi proses informasi di berbagai perpustakaan dan pusat informasi (Shah, S.M., 2016).

Bibliometrika merupakan bagian dari teori informasi yang menganalisis sifat-sifat secara kuantitatif dan perilaku pengetahuan yang direkam. Melalui teknik ini, hal yang dapat dipelajari hanya yang direkam, bukan pengetahuan itu sendiri. Mirip dengan mata pelajaran sains lainnya, disiplin perpustakaan dan ilmu informasi tidak hanya bersandar pada asumsi dan pendapat yang berasal dari pemikiran dan pengalaman (Alagu, A. and Thanuskodi, S., 2019). 
Bibliometrik adalah analisis kuantitatif karakteristik, perilaku, dan produktivitas semua aspek komunikasi tertulis, staf perpustakaan, dan pengguna informasi. Bibliometrik berguna untuk analisis kurikulum dan untuk penilaian kualitas hasil penelitian, dan merupakan salah satu dari alat untuk mengukur kolaborasi penelitian dalam ilmu sosial (Shipra, A., 2019)

Analisis data publikasi memberikan gambaran volume total hasil penelitian, namun tidak memberikan indikasi mengenai kualitas pekerjaan yang dilakukan. Ada beberapa data tentang kutipan yang dapat digunakan untuk evaluasi, umumnya diyakini bahwa makalah yang dikutip lebih banyak dimanfaatkan oleh para peneliti dan karenanya dianggap lebih relevan dengan pekerjaan mereka. Selebihnya, analisis bibliometrik dapat digunakan untuk menentukan area penelitian yang muncul; menganalisis kinerja penelitian masing-masing ilmuwan; kelompok penelitian, lembaga dan negara; menguraikan struktur kognitif atau intelektual dari area penelitian dan menguji hubungan antara penulis, lembaga dan artikel jurnal.

Menurut data sensus penduduk 2010 Indonesia merupakan negara muslim karena mayoritas penduduknya beragama Islam sekitar $87,18 \%$ (Anonim, 2019) . Berbagai informasi tentang Islam tentu sangat dibutuhkan mengingat hingga saat ini masyarakat masih sering membaca berita yang kurang nyaman tentang Islam, seperti adanya teroris di Indonesia. Beberapa berita berkenaan dengan penangkapan teroris diantaranya dimuat dalam CCN Indonesia 01 Juli 2019, dengan head line. Satu bulan sebelumnya berita tentang teroris juga dimuat di CNN Indonesia pada 15 Mei 2019 dengan judul Densus 88 Tangkap 5 Terduga Teroris Jaringan Jamaah Islamiyah. Dalam Sepekan, Densus 88 Tangkap 8 Terduga Teroris di Jateng. Seperti diketahui bahwa keberadaan teroris hampir selalu dikaitkan dengan Islam. Di samping berita yang kurang baik seperti di atas, ada pula berita yang membanggakan yang juga dapat kita dengar seperti yang dimuat dalam detiknews 27 Mei 2019, Indonesia Jadi Juara 1 Tilawah MTQ Internasional di Turki (Fadil,H., 2019). Selain dalam bentuk berita yang diperuntukkan bagi masyarakat luas, para peneliti, akademisi, maupun para ilmuwan juga perlu mengikuti pengetahuan tentang Islam di Indonesia terutama dalam bentuk hasil penelitian, yang dikomunikasikan melalui berbagai saluran diantaranya adalah melalui terbitan ilmiah yang berupa jurnal.

Salah satu jurnal yang fokus pada bidang ilmu sosial dan khusus membahas studi tentang Islam adalah Studia Islamika. Jurnal tersebut merupakan terbitan dari dari Pusat Pengkajian Islam dan Masyarakat (PPIM) Universitas Islam Negeri Syarif Hidayatullah Jakarta, Indonesia. Saat ini terbitan tersebut sudah mendapatkan akreditasi dari Kementerian Riset, Teknologi dan Pendidikan Tinggi melalui Surat Keputusan Nomor 32a/E/KTP/2017 serta diindeks oleh Scopus dan Thomson Reuter.

Dengan demikian mengikuti jurnal Studia Islamika merupakan suatu hal penting bagi para peneliti, ilmuwan dan akademisi di bidangnya. Oleh karena itu diperlukan kajian bibliometrika tentang jurnal tersebut, agar dapat memberikan gambaran kepada para peneliti tentang topik penelitian serta profil dari jurnal tersebut.

Secara bibliometrika, profil dari jurnal Studia Islamika yang tergambar dalam jurnal Studia Islamika belum dideskripsikan serta belum dikomunikasikan ke masyarakat. Oleh karena itu pertanyaan penelitian yang muncul adalah :

1) Berapa jumlah artikel yang dipublikasikan di dalam jurnal tahun Studia Islamika 2014 2018 ?

2) Topik apa saja yang diminati oleh para peneliti dalam Studia Islamika tahun $2014-2018$ ?

3) Siapakah pengarang yang paling produktif menulis dalam tahun Studia Islamika 2014 2018 ?

4) Jenis dokumen apa yang diterbitkan dalam Studia Islamika tahun $2014-2018$ ?

5) Negara mana saja yang berkontribusi dalam Studia Islamika periode $2014-2018$ ?

6) Berapa jumlah sitasi dari Studia Islamika tahun $2014-2018$ ? 
Penelitian bertujuan untuk mengetahui :

1) Jumlah artikel yang dipublikasikan dalam Studia Islamika tahun $2014-2018$.

2) Topik yang menjadi minat penulis pada Studia Islamika tahun $2014-2018$.

3) Pengarang paling produktif dalam Studia Islamika tahun $2014-2018$.

4) Jenis dokumen yang dipublikasikan dalam Studia Islamika tahun $2014-2018$.

5) Negara yang berkontribusi dalam Studia Islamika tahun $2014-2018$.

6) Jumlah sitasi dari Studia Islamika tahun 2014 - 2018.

Beberapa penelitian terdahulu tentang bibliometrika diantaranya adalah sebagai berikut. Kirtania, D.K (2018) melakukan pelacakan pertumbuhan dan perkembangan literatur ilmu sosial di lingkungan akses terbuka yang diterbitkan di India. Total 1.195 makalah yang diterbitkan dan diindeks dalam database Scopus dari tahun 2008 hingga 2017 dianalisis berdasarkan pertumbuhan literatur, pola kepenulisan, indeks aktivitas, penulis dan lembaga yang produktif, jenis publikasi, dan jumlah kutipan telah diperiksa untuk memberikan gambaran yang jelas tentang penelitian ilmu sosial India. Studi ini menunjukkan dominasi kepengarangan bersama dan enam puluh persen dari total artikel telah dikutip.

Analisis bibliometrik dilakukan pada penelitian media sosial dalam jurnal di bawah kategori subjek "Ilmu Informasi \& Ilmu Perpustakaan" dari Indeks Social Science Citation Index. Sebanyak 646 artikel ditelusur menggunakan istilah " social media" sebagai kata kunci untuk mencari bagian dari judul, abstrak atau kata kunci publikasi. Kinerja dan tren penelitian dianalisis dengan deskriptor jenis dan bahasa, karakteristik, negara, jurnal, kepengarangan, dan kata kunci penulis. Hasil menunjukkan bahwa, penelitian media sosial terus meningkat dari periode 2002 hingga 2013 dan luaran publikasi tahunan pada 2012 dan 2013 hampir setengah dari total. Sebanyak 9. 851 halaman, 29. 433 referensi dikutip, 1, 540 penulis dan 3, 740 kutipan diidentifikasi dalam semua 646 artikel, dengan rata-rata per artikel 15,25 halaman, 45,46 referensi dikutip, 2,38 penulis dan 5,79 kutipan. Analisis negara dan jurnal menunjukkan distribusi publikasi yang tidak merata di tingkat nasional dan jurnal. Amerika Serikat mencapai posisi terdepan dengan menyumbang bagian terbesar dari artikel. Inggris, Spanyol dan Cina adalah tiga negara produktif teratas lainnya dalam publikasi total. Sebanyak 73,53\% dari total artikel diterbitkan di 25 jurnal dengan faktor dampak mulai dari 0 hingga 5. Lebih dari setengah $(51,24 \%)$ jurnal memiliki faktor dampak antara 1 dan 3 . Kata kunci penulis yang paling umum digunakan dalam artikel adalah "social media", "social network", "Internet", "communication", "Web 2.0”, "blog", "Twitter", "Facebook" and "virtual community".

Sebanyak 273 artikel dari Journal of Social Sciences periode 2003 - 2007, diteliti secara bibliometrik. Penulis yang berkolaborasi berdua berada pada posisi pertama dengan jumlah 44,33\%. Sebagian besar penulis berasal dari luar India yaitu sebanyak 78,39\% sedangkan kontribusi India kurang. Mayoritas artikel 136 (49,82\%) memiliki panjang 11 halaman dan mayoritas artikel $(55,98 \%)$ menggunakan referensi dari artikel jurnal (Thanuskondi, S., 2010).

Shipra, A. (2019), melakukan analisis untuk menguji pola penelitian kolaboratif dalam Ilmu Sosial di Universitas Jawaharlal Nehru, India selama periode 1998-2017. Sebanyak 2.128 artikel dikumpulkan untuk diteliti. Metode bibliometrik digunakan untuk menghitung penelitian kolaboratif yang meliputi indeks kolaboratif, koefisien kolaboratif, koefisien kolaboratif yang dimodifikasi, tingkat kolaborasi dan indeks co-author.

\section{Database Scopus}

Scopus adalah database abstrak dan pengindeksan dengan tautan teks lengkap yang diproduksi oleh Elsevier Co. Nama itu, Scopus, terinspirasi oleh burung, Hammerkop (Scopus umbretta), yang diperkirakan memiliki keterampilan navigasi yang sangat baik. Basis data, dalam 
pengembangan selama dua tahun, dikembangkan bekerjasama dengan 21 lembaga penelitian dan lebih dari 300 peneliti dan pustakawan. Umpan balik verbal dan perilaku para pustakawan dan penelitian ini dianalisis dan digunakan untuk meningkatkan produk. Pengembang Scopus mengklaim telah mengindeks lebih dari 14.000 Science Technology and Mathematics (STM) dan judul ilmu sosial dari 4.000 penerbit, yang menyatakan bahwa itu adalah database abstrak dan pengindeksan tunggal terbesar yang pernah dibuat. Database mengklaim 4.600 judul ilmu kesehatan diindeks termasuk cakupan MEDLINE, EMBASE dan dari COMPENDEX. Daftar judul yang diindeks dipilih berdasarkan permintaan pengguna dan riset pasar. Database berisi sekitar 27 juta abstrak. Selain jurnal Amerika, itu termasuk sastra Eropa dan Asia Pasifik di Inggris dan luar Inggris. Pengindeksan mencakup nomor registri CAS, istilah MeSH, istilah EMTREE, dan istilah kunci tambahan yang ditambahkan oleh pengindeks. ( Burnham, J.F., 2006).

Penelusuran pada database Scopus dapat dilakukan baik secara basic maupun advance. Penelusuran juga dapat dibatasi dengan menggunakan tanggal, jenis dokumen, subyek. Adapun pada penelusuran advance, dapat menggunakan Boolean operator.

\section{METODE PENELITIAN}

Metode yang digunakan dalam penelitian adalah metode penelusuran terhadap jurnal Studia Islamika, dengan memanfaatkan database Scopus, (http: www.scopus.com) dengan periode pengamatan adalah antara tahun 2014 - 2018. Hasil penelusuran dikelompokkan berdasarkan tahun terbit, jumlah artikel yang diterbitkan, topik yang menjadi minat peneliti, dan produktivitas pengarang.

\section{HASIL DAN PEMBAHASAN \\ Jumlah Artikel Studia Islamika Periode 2014 - 2018}

Berdasarkan Tabel 1 dapat diketahui bahwa selama tahun 2014 - 2018, dipublikasikan sebanyak 82 artikel dalam Studia Islamika. Artikel terbanyak dipublikasikan pada tahun 2016 yaitu sebanyak 18 judul (21,95\%), disusul di tempat ke dua yaitu pada tahun 2017 dan 2014 dengan jumlah 17 judul (20,73\%). Berikutnya di posisi ke tiga adalah pada tahun 2015 dengan jumlah artikel 16 judul (19,52\%), namun pada tahun 2018 terjadi penurunan artikel menjadi 14 judul $(17,07 \%)$.

Tabel 1

Jumlah artikel Studia Islamika tahun 2014 - 2018

\begin{tabular}{ccc}
\hline Tahun & Jumlah Artikel & Persentase \\
\hline 2018 & 14 & 17,07 \\
2017 & 17 & 20,73 \\
2016 & 18 & 21,95 \\
2015 & 16 & 19,52 \\
2014 & 17 & 20,73 \\
Jumlah & 82 & 100 \\
\hline Sumber $:$ http://www/scopus.com, diakses 09 Juli 2019.
\end{tabular}

\section{Topik yang Diminati}

Sebanyak 30 topik diminati peneliti dan dipublikasikan dalam Studia Islamika 2014-2018, dan Islam merupakan topik yang paling banyak diteliti, dan diwakili oleh $8(10,26 \%)$ judul artikel. Topik kedua yang paling banyak diteliti adalah Indonesia dengan 6 (7,70 \%) judul artikel. Topik ketiga yang paling banyak diteliti adalah Muhammadiyah dan orde baru dengan masing-masing 4 $(5,13 \%)$ artikel. Empat topik yang paling banyak diteliti adalah Malaysia, Pancasila, dan Sundanece dengan masing-masing 3 (3,85\%) judul artikel. Untuk lebih jelasnya frekuensi bidang minat yang diterbitkan dalam jurnal Studia Islamika dapat dilihat pada Tabel 2 di bawah ini. 
Tabel 2

Topik Penelitian Studia Islamika tahun 2014 - 2018

\begin{tabular}{|c|c|c|}
\hline Topik & Jumlah & Persentase \\
\hline Islam & 8 & 10,26 \\
\hline Indonesia & 6 & 7,70 \\
\hline Muhammadiyah & 4 & 5,14 \\
\hline New Order & 4 & 5,14 \\
\hline Malaysia & 3 & 3,86 \\
\hline Pancasila & 3 & 3,86 \\
\hline Sundanese & 3 & 3,86 \\
\hline Tradition & 3 & 3,86 \\
\hline Acculturation & 2 & 2,56 \\
\hline Community & 2 & 2,56 \\
\hline Democracy & 2 & 2,56 \\
\hline History & 2 & 2,56 \\
\hline Human Right & 2 & 2,56 \\
\hline Identity & 2 & 2,56 \\
\hline Integration & 2 & 2,56 \\
\hline Islamic Modernism & 2 & 2,56 \\
\hline Islamization & 2 & 2,56 \\
\hline Kyai & 2 & 2,56 \\
\hline Madrasah & 2 & 2,56 \\
\hline Malay Language & 2 & 2,56 \\
\hline Mysticism & 2 & 2,56 \\
\hline Nahdlatul Ulama & 2 & 2,56 \\
\hline Pesantren & 2 & 2,56 \\
\hline Reform & 2 & 2,56 \\
\hline Religion & 2 & 2,56 \\
\hline Ritual & 2 & 2,56 \\
\hline Soeharto & 2 & 2,56 \\
\hline Southeast Asia & 2 & 2,56 \\
\hline Tolerance & 2 & 2,56 \\
\hline Zakat & 2 & 2,56 \\
\hline Total & 78 & 100 \\
\hline
\end{tabular}

Sumber : http://www.scopus.com, diakses 09 Juli 2019

\section{Produktivitas Penulis}

Berdasarkan Tabel 3 diketahui bahwa sebanyak 82 nama muncul sebagai punulis pada Studia Islamika tahun 2014 - 2018. Adapun Darmadi berada di posisi pertama sebagai penulis paling produktif, dengan jumlah tulisan sebanyak 3 judul artikel. Berikutnya di tempat ke dua ditempati oleh tujuh orang berturut - turut adalah Burhanudin, J., Fadlan, M.N., Garadian, E.A., Jahroni, J., Munhanif, A., Saputra, R.E., dan Yakin, A.U, dengan jumlah tulisan masing - masing sebanyak 2 judul artikel. Dengan demikian 65 penulis menerbitkan 1 judul artikel pada Studia Islamika.

Tabel 3

Produktivitas penulis Studia Islamika tahun 2014 - 2018

\begin{tabular}{ccc}
\hline Penulis & Jumlah & Persentase (\%) \\
\hline Darmadi, D. & 3 & 3,20 \\
Burhanudin, J. & 2 & 2,20 \\
Fadlan, M.N. & 2 & 2,20 \\
Garadian, E.A. & 2 & 2,20 \\
Jahroni, J. & 2 & 2,20 \\
Munhanif, A. & 2 & 2,20 \\
Saputra, R.E. & 2 & 2,20 \\
Yakin, A.U. & 2 & 2,20 \\
Abdallah & 1 & 1,10 \\
\hline
\end{tabular}




\begin{tabular}{|c|c|c|}
\hline Abushouk, A.I. & 1 & 1,10 \\
\hline Ahyar, M. & 1 & 1,10 \\
\hline Ali, M. & 1 & 1,10 \\
\hline Amanullah, M. & 1 & 1,10 \\
\hline Ansor, M. & 1 & 1,10 \\
\hline As'ad, M. & 1 & 1,10 \\
\hline Brice, M.A.K. & 1 & 1,10 \\
\hline Bustamam-Ahmad, K. & 1 & 1,10 \\
\hline Bustamam-Ahmad, K. & 1 & 1,10 \\
\hline Dhuhri, S. & 1 & 1,10 \\
\hline Drakeley, S. & 1 & 1,10 \\
\hline Fauzi & 1 & 1,10 \\
\hline Gamon, A.D. & 1 & 1,10 \\
\hline Ghaleb, Y.M.A. & 1 & 1,10 \\
\hline Hafiz, M. & 1 & 1,10 \\
\hline Hakim, S.A. & 1 & 1,10 \\
\hline Harisudin, M.N. & 1 & 1,10 \\
\hline Hasanah, A. & 1 & 1,10 \\
\hline Hermansyah & 1 & 1,10 \\
\hline Hongxuan, L. & 1 & 1,10 \\
\hline Iskandar, M. & 1 & 1,10 \\
\hline Islam, M.A.M. & 1 & 1,10 \\
\hline Ismail, F. & 1 & 1,10 \\
\hline Ismail, N.B. & 1 & 1,10 \\
\hline Jahar, A.S. & 1 & 1,10 \\
\hline Jakarta, S.H. & 1 & 1,10 \\
\hline Kirana, D. & 1 & 1,10 \\
\hline Latif, Y. & 1 & 1,10 \\
\hline Makin, A. & 1 & 1,10 \\
\hline Marhayati, N. & 1 & 1,10 \\
\hline Maulana, D. & 1 & 1,10 \\
\hline Miswari & 1 & 1,10 \\
\hline Moriyama, M. & 1 & 1,10 \\
\hline Mujiburrahman & 1 & 1,10 \\
\hline Nahdi, M.S. & 1 & 1,10 \\
\hline Nasuhi, H. & 1 & 1,10 \\
\hline Njoto-Feinard, G. & 1 & 1,10 \\
\hline Noor, F. & 1 & 1,10 \\
\hline Octavia, L. & 1 & 1,10 \\
\hline Pribadi, Y. & 1 & 1,10 \\
\hline Rahman, M.F.A. & 1 & 1,10 \\
\hline Raihani & 1 & 1,10 \\
\hline Reid, A. & 1 & 1,10 \\
\hline Ricklefs, M.C. & 1 & 1,10 \\
\hline Riddell, P.G. & 1 & 1,10 \\
\hline Rohayati, T. & 1 & 1,10 \\
\hline Rohmana, J.A. & 1 & 1,10 \\
\hline Ropi, I. & 1 & 1,10 \\
\hline Saat, N. & 1 & 1,10 \\
\hline Salam, M.I.H.A. & 1 & 1,10 \\
\hline Salim, A. & 1 & 1,10 \\
\hline Shiozaki, Y. & 1 & 1,10 \\
\hline Sila, M.A. & 1 & 1,10 \\
\hline Siregar, H. & 1 & 1,10 \\
\hline Soemitra, A. & 1 & 1,10 \\
\hline Steele, J. & 1 & 1,10 \\
\hline Suaedy, A. & 1 & 1,10 \\
\hline Suharto, T. & 1 & 1,10 \\
\hline Sulistiyowati, E. & 1 & 1,10 \\
\hline Subekti, V.S. & 1 & 1,10 \\
\hline Supratman, F.R. & 1 & 1,10 \\
\hline Suryadilaga, M.A. & 1 & 1,10 \\
\hline Suryanto & 1 & 1,10 \\
\hline
\end{tabular}




\begin{tabular}{ccc}
\hline Tagoranao, M.S. & 1 & 1,10 \\
Trotier, F. & 1 & 1,10 \\
Ubaedillah, A. & 1 & 1,10 \\
Umar, A.R.M. & 1 & 1,10 \\
Widiyanto, A. & 1 & 1,10 \\
Wirman, E.P. & 1 & 1,10 \\
Yamaguchi, M. & 1 & 1,10 \\
Zakaria, R. & 1 & 1,10 \\
Zulkifli & 1 & 1,10 \\
Özay, M. & 1 & 1,10 \\
Total & 82 & 100 \\
\hline
\end{tabular}

\section{Documents by author}

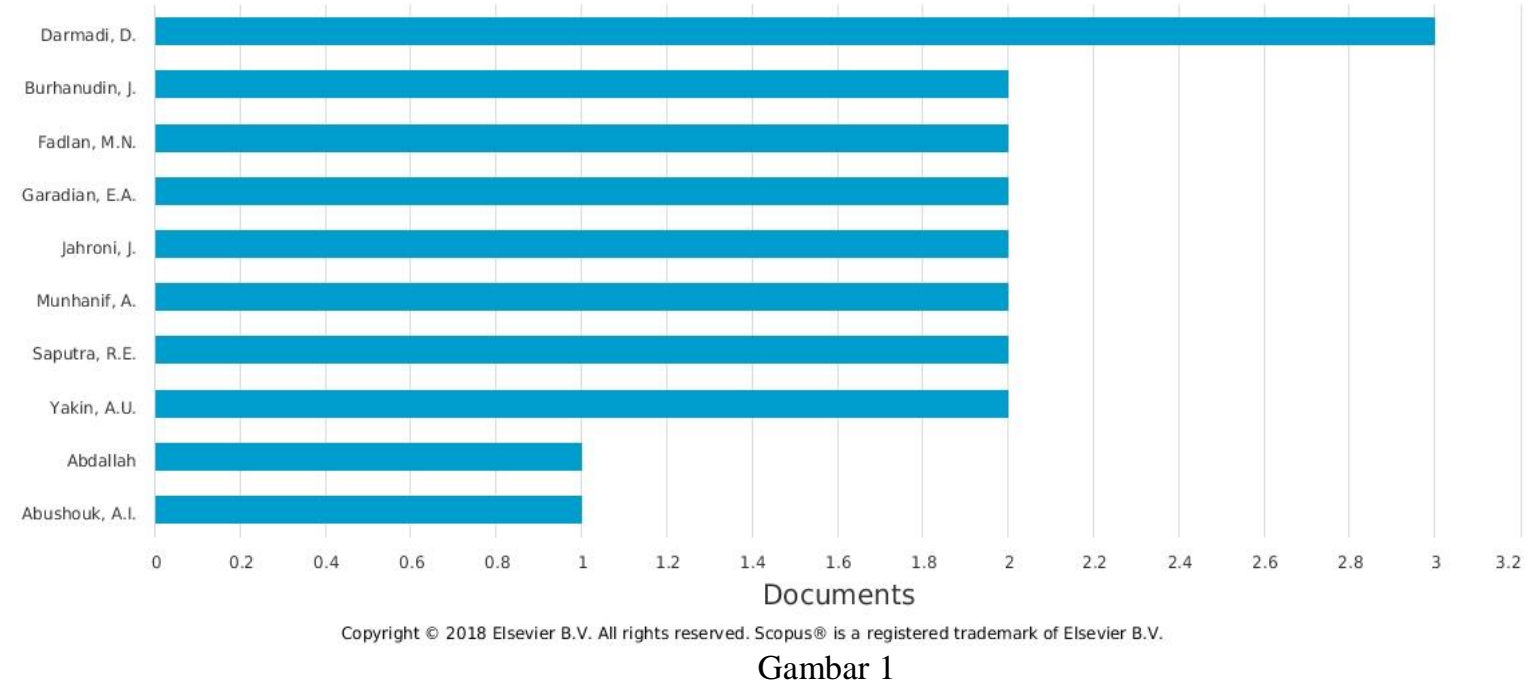

Produktivitas pengarang dalam penelitian ilmu sosial di studi Islam Sumber: http:www.scopus.com, diakses 09Juli 2019

\section{Negara yang Berkontribusi dalam Tulisan}

Tabel 4 di bawah ini menunjukkan bahwa apabila dilihat dari kontribusi negara, maka dapat diketahui bahwa posisi pertama berasal kota Indonesia, yaitu berjumlah 43 judul artikel. Hal ini dapat dimengerti karena jurnal Studia Islamika adalah jurnal terbitan dari Universitas Islam Indonesia Syarif Hidayatullah, maka sangat wajar apabila kontribusi terbesar berasal dari Indonesia. Pada posisi kedua adalah Australia sebanyak 6 judul artikel. Hal ini karena Australia adalah negara bukan muslim yang bertetangga dekat dengan Indonesia, oleh karena itu para peneliti di negara tersebut sangat ingin mengetahui dan tertarik dengan Islam oleh karena itu mereka melakukan penelitian dan melakukan publikasi melalui jurnal Studia Islamika. Inggris dan Amerika Serikat 5 judul artikel, seperti halnya Australia, Inggris dan Amerika Serikat merupakan negara yang sangat mewaspadai akan keberadaan Islam terlebih sejak peristiwa teror bom 11 September 2001 di World Trade Center Amerika Serikat, maka sudah sewajarnya apabila peneliti di negara tersebut memberikan perhatian terhadap perkembangan penelitian tentang Islam, juga berkontribusi menuliskan hasil penelitian mereka pada Studia Islamika. Berikutnya adalah Jepang dengan 3 judul artikel, Jepang adalah mantan negara penjajah Indonesia, maka negara tersebut tentu ingin mengetahui sekaligus berpartisipasi dalam menyumbangkan hasil penelitiannya tentang ilmu sosial terutama yang berkaitan dengan Islam. Adapun negara - negara Jerman, India , Malaysia, Singapura dan Turki masing - masing 1 judul artikel, selain Jerman, India, Malaysia, Singapura dan Turki juga banyak penduduk muslimnya, maka wajar jika peneliti mereka juga berkontribusi di jurnal Studia Islamika. 
Tabel 4

Sepuluh besar negara yang menyumbang tulisan di Studia Islamika tahun $2014-2018$

\begin{tabular}{ccc}
\hline Negara & Jumlah & Persentase (\%) \\
\hline Indonesia & 43 & 49,43 \\
Australia & 6 & 6,89 \\
Inggris & 5 & 5,76 \\
Amerika Serikat & 5 & 5,76 \\
Japang & 3 & 3,45 \\
Jerman & 1 & 1,15 \\
India & 1 & 1,15 \\
Malaysia & 1 & 1,15 \\
Singapora & 1 & 1,15 \\
Turki & 1 & 1,15
\end{tabular}

Documents by country or territory

compare the document counts for up to 15 countries/territories

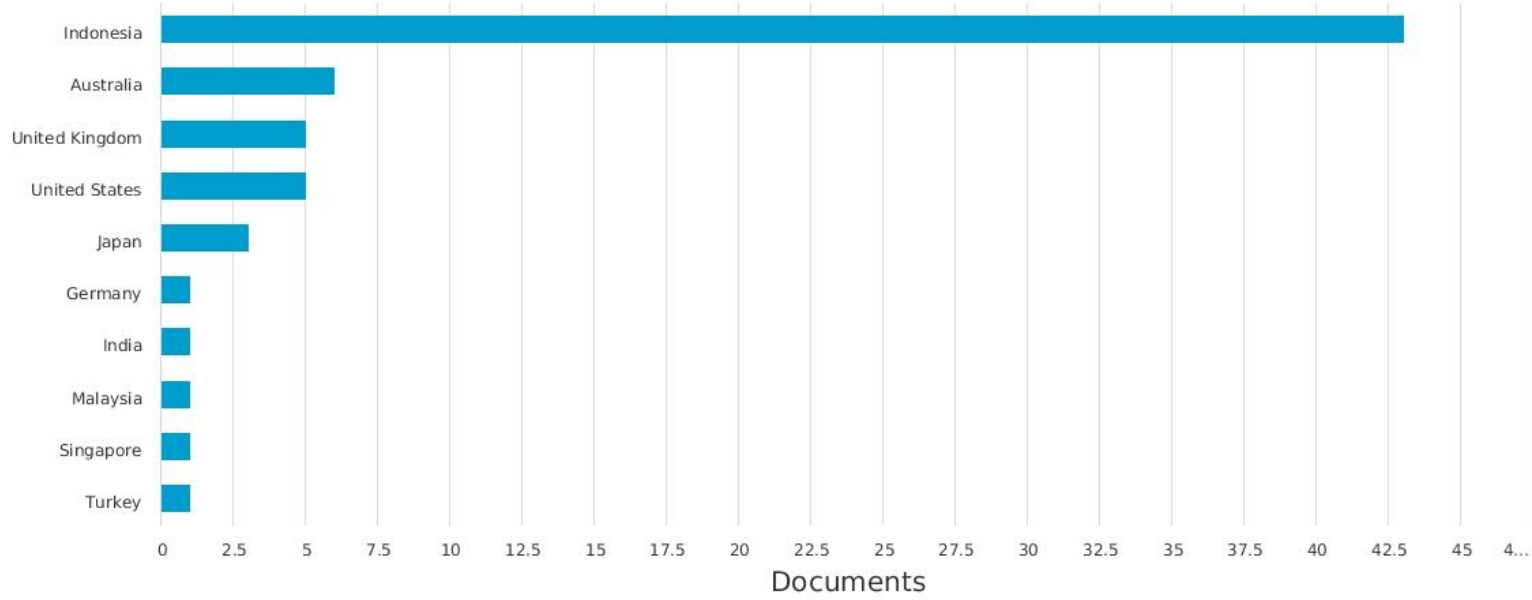

Copyright $\odot 2018$ Elsevier B.V. All rights reserved. Scopus $\circledast$ is a registered trademark of Elsevier B.V.

Gambar 2

Sepuluh besar negara kontibutor artikel pada Studia Islamikatahun 2014 - 2018

Sumber: http:www.scopus.com, diakses 09Juli 2019

\section{Jenis dokumen}

Jenis dokumen yang diterbitkan pada Studia Islamika dapat dilihat pada Tabel 5 dan Gambar 3 berikut ini. Tinjauan merupakan jenis dokumen terbanyak yaitu 46 judul (56,09\%), kemudian artikel merupakan jenis terbanyak ke dua yaitu 33 judul (40,24\%) adapun sisanya adalah makalah konferensi sebanyak 2 judul $(2,44 \%)$ dan editorial 1 judul $(1,22 \%)$. Hal tersebut menunjukkan bahwa para peneliti lebih menyukai penelitian dalam bentuk review dibandingkan dalam bentuk artikel.

Tabel 5

Jenis dokumen

\begin{tabular}{llc}
\hline Jenis dokumen & Jumlah & Persentase (\%) \\
\hline Tinjauan/review & 46 & 56,09 \\
Artikel & 33 & 40,24 \\
Makalah konferensi & 2 & 2,44 \\
Editorial & 1 & 1,23 \\
Jumlah & 82 & 100 \\
\hline
\end{tabular}




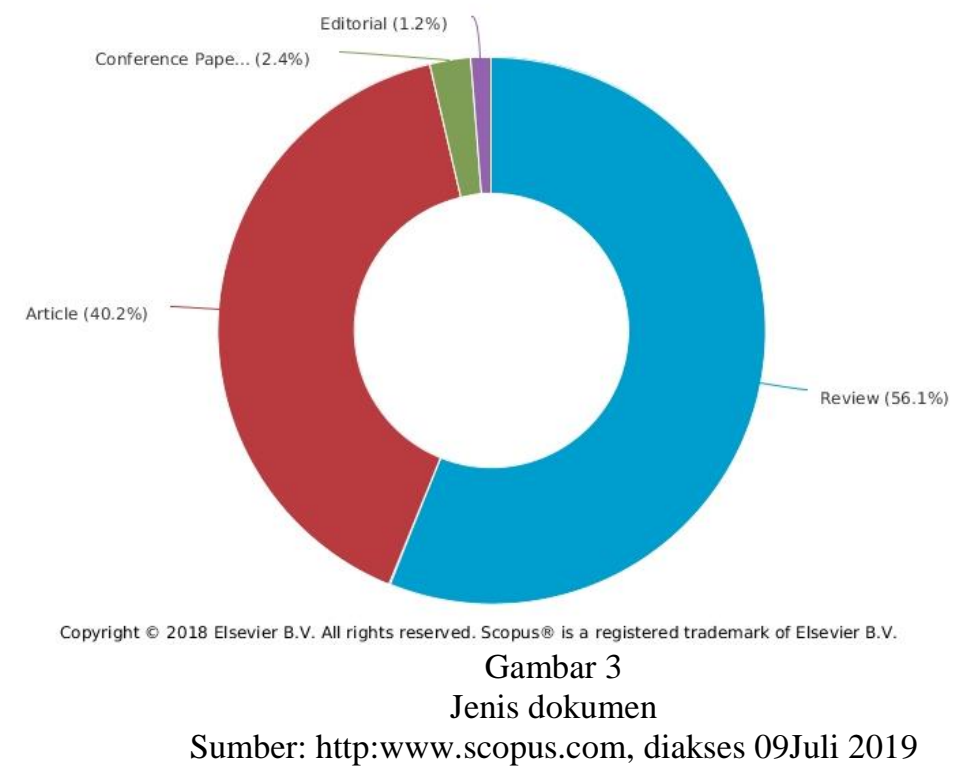

\section{Afiliasi Penulis yang Menulis Lebih Dari Satu Dokumen}

Diketahui terdapat delapan institusi yang menulis lebih dari satu dokumen pada Studia Islamika tahun 2014 - 2018, seperti yang dituangkan dalam Tabel 6 dan Gambar 4 di bawah ini. Sejalan dengan negara, maka institusi di Indonesia merupakan penyumbang artikel terbanyak di dalamnya termasuk UIN Syarif Hidayatullah Jakarta di peringkat pertama (21 artikel) , kemudian Institut Agama Islam Negeri menyumbang 5 artikel, Universitas Islam Negeri Sunan Kalijaga Yogyakarta (3 artikel) dan terakhir adalah Univeritas Indonesia (2 artikel)

Tabel 6

Afiliasi penulis yang menulis lebih dari satu dokumen

\begin{tabular}{lc}
\hline \multicolumn{1}{c}{ Afiliasi } & Jumlah dokumen \\
\hline Universitas Islam Negeri Syarif Hidayatullah & 21 \\
Jakarta & 5 \\
State Institute for Islamic Studies IAIN & 3 \\
Australian National University & 3 \\
Universitas Islam Negeri Sunan Kalijaga, & \\
Yogyakarta & 2 \\
Japan Society for the Promotion of Science & 2 \\
Western Sydney University & 2 \\
University of Exeter & 2 \\
Universitas Indonesia & \\
\hline
\end{tabular}




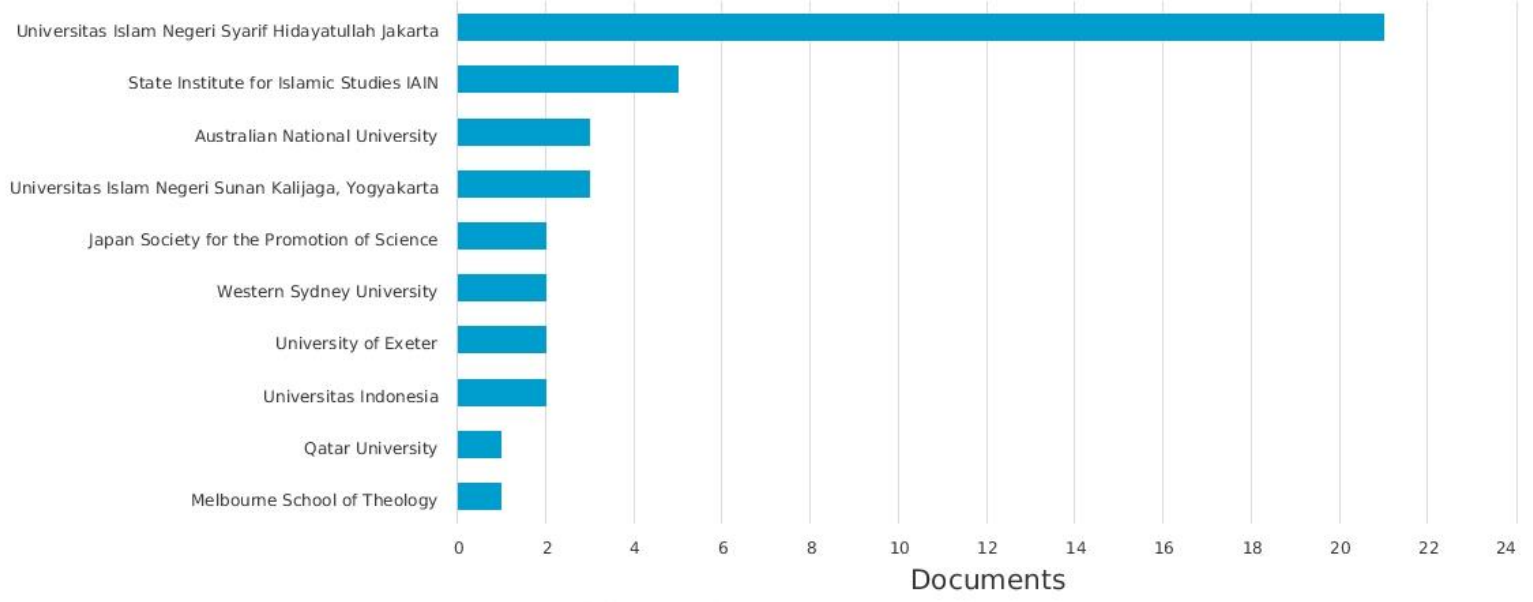

Copyright $\odot 2018$ Elsevier B.V. All rights reserved. Scopus $\circledast$ is a registered trademark of Elsevier B.V.

Gambar 4

Artikel menurut afiliasi

Sumber: http:www.scopus.com, diakses 09Juli 2019

\section{Jumlah Sitasi}

Berdasarkan hasil pencarian melalui https://scholar.google.co.id/citations dan http://sinta2.ristekdikti.go.id diketahui bahwa jumlah kutipan dari Studia Islamika selama periode 2014 hingga 2018 seperti yang ditunjukkan pada Tabel 7. Jumlah kutipan maksimum berada pada tahun 2017, yaitu 236 kutipan, (27,38\%), diikuti pada tahun 2016 yaitu 189 kutipan (21,93\%), tahun 2015 sebanyak 165 kutipan (19,14\%), tahun 2018 sebanyak 161 kutipan, (18,67\%) dan tahun 2014 berjumlah 111 kutipan $(12,88 \%)$. Apabila dicermati telah terjadi kenaikan jumlah kutipan di setiap tahun sejak 2014 - 2017, namun pada 2018 jumlah kutipan menurun. Pada periode 2014 - 2017 jurnal Studia Islamika memilih artikel dengan cermat dalam rangka akreditasi jurnal serta agar terindeks di Scopus, namun pada 2018 terjadi penurunan karena pemilihan topik penelitian kurang menarik atau di luar tren.

Tabel 7

Jumlah sitasi dalam Studia Islamika

\begin{tabular}{ccc}
\hline Tahun & Jumlah kutipan & Persentase (\%) \\
\hline 2014 & 111 & 12,88 \\
2015 & 165 & 19,14 \\
2016 & 189 & 21,93 \\
2017 & 236 & 27,38 \\
2018 & 161 & 18,67 \\
Jumlah & 862 & 100 \\
\hline
\end{tabular}

\section{SIMPULAN}

Berdasarkan hasil dan pembahasan dapat disimpulkan bahwa Studia Islamika merupakan salah satu jurnal tentang studi Islam terbitan Universitas Islam Negeri Syarif Hidayatullah Jakarta. Studia Islamika telah dikenal di dunia yang dibuktikan antara lain para kontributornya tidak hanya dari Indonesia, namun juga berasal dari berbagai institusi dari negara lain seperti Australia, Amerika, Jepang, India, dan Malaysia. Terlebih lagi jurnal ini telah diindeks oleh Scopus. Pada tahun 2014 -2018 telah diterbitkan 82 artikel, dengan topik yang diminati adalah tentang Islam. Tulisan jenis review lebih banyak dipublikasikan dibandingkan dengan artikel serta makalah dengan jumlah kutipan selama tahun 2014 -2018 adalah 862 kali. Penulis terbanyak berasal dari UIN Syarif Hidayatullah dan penulis yang paling produktif adalah Darmadi. 


\section{DAFTAR PUSTAKA}

Alagu, A. and Thanuskodi, S.(2019). Bibliometric Analysis of Digital Literacy Research Output: A Global Perspective.(2019) Library Philosophy and Practice (e-journal). 2127. http://digitalcommons.unl.edu/libphilprac/2127

Ahmed, Aquil and Al-Reyaee, Sulaiman. (2019). Bibliometric Analysis of Research Publications of Al-Jouf University, Saudi Arabia during the Year 2006-2017. Library Philosophy and Practice (e-journal). 2476. https://digitalcommons.unl.edu/libphilprac/2476

Anonim.(2019). Agama di Indonesia. https://id.wikipedia.org/wiki/Agama_di_Indonesia.Diakses 21 Oktober 2019.

Burnham.J.F. (2006). Resources Rivew Scopus Database : A Review. Biomedical Digital Library . 2006, 3:1 doi:10.1186/1742-5581-3-.

CNN Indonesia. (2019).Densus 88 Tangkap 5 Terduga Teroris Jaringan Jamaah Islamiyah. Diunduh dari https://www.cnnindonesia.com/nasional/20190701140303-12-407956/densus88-tangkap-5 terduga-teroris-jaringan-jamaah-islamiyah

CNN Indonesia. (2019).Dalam sepekan, Densus 88 Tangkap 8 Terduga Teroris di Jateng. Diunduh dari https://www.cnnindonesia.com/nasional/20190515111225-12-395027/dalam-sepekandensus-88-tangkap-8-terduga-teroris-di-jateng, diakses 15 Juli 2019.

Fadil, H. (2019). Indonesia Jadi Juara 1 Tilawah MTQ Internasional di Turki. Diunduh dari https://news.detik.com/berita/d-4566128/indonesia-jadi-juara-1-tilawah-mtq-internasionaldi-turki

Gan, C and Wang, W. (2014). A bibliometric analysis of social media from the perspective of library and information science. IFIP Advances in Information and Communication Technology 445, pp. 23-32.

Judy, F.B. (2006). Resources Rivew.Scopus database : A Review. Biomedical Digital Library . 2006, 3:1 doi:10.1186/1742-5581-3-1

Kirtania, D.K. (2018). Bibliometric study of Indian open access social science literature. Library Philosophy and Practice. Article number 1867.

Scopus. (2019). Document by affiliation. Diunduh dari http://www.scopus.com

Scopus. (2019). Document by author. Diunduh dari http//www.scopus.com

Scopus. (2019). Document by country of territory. Diunduh dari http://www.scopus.com

Scopus. (2019). Document by type. (2019). Diunduh dari http://www.scopus.com

Shah, S.M; (2016). A Bibliometric Analysis of International Journal of Agriculture Sciences (2009-2014). Asian Journal of Multidisciplinary Studies; 4 (2): 151- 157.

Shipra, A. (2019). A Bibliometric study on Collaborative Research in Social Sciences at Jawaharlal Nehru University, India: A Glimpse from Scopus Database. Library Progress (International), 39 (1): 70-80, DOI: 10.5958/2320-317X.2019.00007.2 
S. Thanuskodi. (2010). Journal of Social Sciences: A Bibliometric Study. Journal of Social Sciences, 24:2, 77-80, DOI: 10.1080/09718923.2010.11892847.

Sridevi, T.R. (2014). Research Evaluation of Indian Journal of Cancer: A Bibliometric Study. Research Journal of Library Sciences. 2 (2) : 1-5. 